\title{
ElF5 wt Allele
}

National Cancer Institute

\section{Source}

National Cancer Institute. EIF5 wt Allele. NCI Thesaurus. Code C104661.

Human EIF5 wild-type allele is located in the vicinity of $14 q 32.32$ and is approximately 11 $\mathrm{kb}$ in length. This allele, which encodes eukaryotic translation initiation factor 5 protein, is involved in both GTP hydrolysis and the association of the 405 and 605 ribosomal subunits. 